\title{
PENGOMPOSAN LIMBAH SAYUR DENGAN EMPAT ISOLAT Trichoderma harzianum DAN PENGARUHNYA TERHADAP PERTUMBUHAN TANAMAN MENTIMUN IN PLANTA
}

\section{Vegetable Waste Decomposition using Four Trichoderma harzianum isolates and its Effect on In Planta Cucumber Growth}

\author{
Fida Suci Ersapoetri, Loekas Soesanto*, Endang Mugiastuti, Ruth Feti Rahayuniati, \\ Abdul Manan dan Slamet Rohadi \\ Fakultas Pertanian, Universitas Jenderal Soedirman, Purwokerto \\ Jl. Dr Suparno 61 Karangwangkal Purwokerto
}

Alamat korespondensi: lukassusanto26@gmail.com

\begin{abstract}
ABSTRAK
Penelitian bertujuan mengetahui kemampuan empat isolat Trichoderma harzianum dalam mengomposkan limbah sayur, isolat $T$. harzianum terbaik pada pengomposan limbah sayur, dan isolat $T$. harzianum terhadap pertumbuhan tanaman mentimun in planta. Penelitian dilaksanakan di rumah kaca dan Laboratorium Perlindungan Tanaman, Fakultas Pertanian, Universitas Jenderal Soedirman, Purwokerto selama lima bulan. Rancangan Acak Kelompok digunakan dengan empat ulangan dan kombinasi antara empat isolat T. harzianum (T10, T213, T14, dan T15) dengan dua limbah sayur (kubis dan tomat). Variabel yang diamati adalah panjang tanaman, bobot tanaman segar, bobot tanaman kering, panjang akar, jumlah daun, $\mathrm{pH}$ akhir kompos, $\mathrm{C} / \mathrm{N}$ ratio kompos, kepadatan akhir T. harzianum, kegigasan T. harzianum, dan analisis jaringan secara kualitatif. Hasil penelitian menunjukkan bahwa keempat isolat $T$. harzainum efektif dan cepat dalam mengkomposkan limbah tomat dan kubis. Isolat $T$. harzianum yang paling baik pada pengomposan adalah T10 dan T213. Aplikasi kompos limbah mampu meningkatkan pertumbuhan tanaman mentimun. Isolat terbaik adalah T. harzianum T16 pada kompos tomat dan T10 pada kompos kubis dalam meningkatkan pertumbuhan tanaman mentimun pada panjang tanaman, panjang akar, bobot tanaman segar, dan bobot tanaman kering dengan peningkatan masing-masing 66,61 dan 52,17\%, 61,01 dan $46,55 \%, 76,41$ dan $59,77 \%$, serta 77,99 dan $52,03 \%$.
\end{abstract}

Kata kunci: limbah sayur, mentimun, pengomposan, Trichoderma harzianum.

\section{ABSTRACT}

The aimed of this research were to determine the ability of four Trichoderma harzianum isolates (T10, T14, T213, and T16) in decomposing vegetable waste (cabbage and tomatoes) decomposition, the best T. harzianum isolate in decomposing the vegetable waste, and the effect of T. harzianum decomposted vegetable waste on growth of cucumber growth. The research was carried out at the green house and the Laboratory of Plant Protection, Faculty of Agriculture, Jenderal Sudirman University, Purwokerto for five months. Randomized block design was used with four replicates. The treatments tested were combination of four T. harzianum isolates (T10, T213, T14, dan T15) and two vegetable waste (cabbage and tomato). Variables observed were crop length, crop fresh weight, crop dry weight, root length, number of leaves, compost late $\mathrm{pH}, \mathrm{C} / \mathrm{N}$ ratio of the compost, late density of $\mathrm{T}$. harzianum, viability of $\mathrm{T}$. harzianum, and qualitatively tissue analysis. Result of the research showed that application of $\mathrm{T}$. harzianum isolates was effective and fast to decompose the vegetable waste. The best $\mathrm{T}$. harzianum isolate to decompose was T10 and T213 isolates. The waste compost application could increase cucumber growth. The best T. harzianum isolate was T16 in tomato waste compost and T10 isolate in cabbage waste compost with increasing cucumber growth of cucumber length, root length, fresh crop weight, and dry crop weight as 66.61 and $52.17 \%, 61.01$ and $46.55 \%, 76.41$ and $59.77 \%$, and 77.99 and $52.03 \%$, respectively.

Keywords: cucumber, composting, Trichoderma harzianum, waste vegetable

\section{PENDAHULUAN}

Perkembangan wilayah pertanian

yang intensif yang didasarkan kepada

irigasi dan aplikasi pupuk nitrogen merupakan pengaruh serius bagi ekosistem tanah. Hal ini berakibat kepada polusi lingkungan, konsentrasi nitrogen yang tinggi, dan tertumpuknya pada bahan 
tanaman yng dikonsumsi (Liu et al., 2014). Pupuk organik diusulkan menjadi salah satu jalan keluar terhadap permasalahan tersebut, karena bahan organik dapat memperbaiki struktur tanah, meningkatkan kapasitas menahan air, dan mendukung perubahan hayati di dalam tanah (Gmach et al., 2020). Salah satu masalah yang sering dihadapi di lapangan adalah terbatasnya produksi pupuk organik di kalangan petani.

Mentimun merupakan tanaman sayuran utama yang dibudidayakan oleh petani di Indonesia. Produksi mentimun di Indonesia mengalami penurunan dari tahun 2010 hingga tahun 2015 (Badan Pusat Statistik, 2017). Penurunan hasil ini disebabkan oleh beberapa faktor antara lain sistem budidaya yang belum intensif dan rendahnya kesuburan tanah. Oleh karena itu, diperlukan perbaikan tehnik budidaya tanaman mentimun. Salah satu teknik budidaya yang intensif untuk meningkatkan hasil panen mentimun adalah pembetian pupuk organik.

Limbah sesayuran merupakan bagian sayur yang tidak termakan yang dibuang selama pengumpulan, penanganan, pengangkutan, dan pemrosesan (Ishangulyyev et al., 2019). Limbah organik ini mempunyai sifat mudah terurai oleh organisme dan mempunyai kandungan kelembapan yang tinggi (Srivastava et al., 2014) serta kandungan nutrisi yang tinggi (Varma and Kalamdhad, 2014). Pasar tradisional menghasilkan limbah organik dalam jumlah yang cukup besar. Limbah tersebut berupa limbah sayuran yang hanya ditumpuk di tempat pembuangan, selain limbah anorganik (Padmi et al., 2018). Limbah sayur pada kenyataannya akan menimbulkan gangguan lingkungan, masalah kesehatan dengan adanya kontaminan dan patogen, serta bau yang tidak sedap (Samaniego et al., 2017).

Salah satu cara untuk mengatasi limbah organik adalah dengan pengomposan menggunakan mikroba. Hal ini yang menyebabkan stuktur tanah yang padat menjadi gembur. Trichoderma harzianum merupakan salah satu jamur mikroparasit, yang dapat digunakan sebagai pengompos limbah organik (Islam et al., 2014) dan dapat dimanfaatkan sebagai agensia pengendali hayati terhadap beberapa jenis jamur fitopatogen (Munir et al., 2013; Ghazanfar et al., 2018). T. harzianum sebagai organisme pengurai dan perangsang pertumbuhan tanaman. $T$. harzianum yang diberikan ke areal pertanaman mendekompos limbah organik menjadi kompos bermutu. T. harzianum menghasilkan enzim, seperti kitinase, glukanase, pektinase, selulase, dan silanase (Bhale and Rajkonda, 2012), ramah lingkungan dan dapat mengembalikan keseimbangan alam dan kesuburan tanah (Bhale and Rajkonda, 2012). 
Trichoderma sp. merupakan jamur yang hidup bebas, yang banyak terdapat di dalam tanah dan sistem akar serta diketahui dapat melarutkan fosfat dan unsur mikrohara (Saravanakumar, 2013). Beberapa isolat Trichoderma sp. telah diisolasi dari beberapa perakaran tanaman dan diidentifikasi sebagai T. harzianum, di antaranya $T$. harzianum isolat T10 dari perakaran tanaman jahe (Soesanto et al., 2013), T14 dari perakaran tanaman nenas (Latifah et al., 2012), T213 dari perakaran tanaman bawang merah (Santoso et al., 2007), dan T16 dari perakaran tanaman pisang (Soesanto et al., 2013).

Atas dasar hal tersebut, penelitian ini dilakukan dengan tujuan mengetahui kemampuan empat isolat T. harzianum (T10, T14, T213, dan T16) dalam mengompos limbah sayur (kubis krop dan tomat), mengetahui isolat $T$. harzianum terbaik pada pengomposan limbah sayur, dan mengetahui isolat $T$. harzianum paling efektif bagi pertumbuhan tanaman mentimun.

\section{METODE PENELITIAN}

Penelitian dilaksanakan di Laboratorium Perlindungan Tanaman dan di Rumah Kaca, Fakultas Pertanian, Universitas Jenderal Soedirman. Penelitian berlangsung pada bulan Mei - September 2013. Penelitian dilaksanakan dalam beberapa tahapan penelitian.
Empat isolat $T$. harzianum $\mathrm{T} 10$ (Soesanto et al., 2013), T14 (koleksi L. Soesanto), T16 (Soesanto et al., 2013), dan T213 (Soesanto et al., 2013) ditumbuhkan dan diperbanyak pada medium Potato Dextrose Agar (PDA), selama 6 hari. Selanjutnya dipanen dan diperbanyak kembali pada medium jagung, diinkubasi selama 10-12 hari dan dihitung kepadatannya (Heydari \& Pessarakli, 2010). Kepadatan konidium T. harzianum yang diaplikasikan untuk isolat T10, T14, T16, dan T213 masing-masing sebesar $2,3 \times 10^{7}, 1,1 \times 10^{7}, 3,2 \times 10^{7}$, dan $6,6 \times 10^{8}$ konidium $/ \mathrm{mL}$.

Limbah tomat dan limbah kubis berupa sayur busuk dan rusak diperoleh dari Pasar Wage Purwokerto, kemudian dibersihkan dari campuran plastik lalu dikering-anginkan. Limbah tomat dan limbah kubis ditimbang masing- masing 1 $\mathrm{kg}$ dan dimasukkan ke dalam ember yang telah diberi label. T. harzianum yang telah diperbanyak di medium jagung pecah ditimbang sebanyak 1800 g. T. harzianum kemudian dicampur dengan limbah hingga merata (limbah yang akan digunakan dicacah atau dipotong kecil terlebih dahulu). Limbah kubis dan tomat yang telah tercampur dengan $T$. harzianum kemudian disimpan dalam ember tertutup, dan ditunggu pengomposan selama 3 minggu.

Benih mentimun yang digunakan adalah Mercy F1. Medium tanam yang 
digunakan adalah campuran tanah Andosol dan kompos dengan perbandingan $1: 2$ (Elpawati et al., 2015). Campuran tersebut dimasukkan dalam gelas plastik dengan volume $240 \mathrm{~mL}$ dan ditata sesuai rancangan dengan jarak antar-gelas plastik $15 \mathrm{~cm}$.

Penelitian ini dilakukan dengan menggunakan Rancangan Acak Kelompok (RAK). Perlakuan yang dicoba yaitu gabungan antara perlakuan $T$. harzianum T10, T16, T14, dan T213 dengan limbah sayur kubis dan tomat. Perlakuan diulang 4 kali dengan tiap unit percobaan terdiri atas 3 tanaman, sehingga total tanaman sebanyak 96 tanaman.

Variabel yang diamati adalah:

1. Analisis Kandungan Fenol

Analisis kandungan senyawa fenol dilakukan dengan menguji kandungan senyawa fenol secara kualitatif terhadap glikosida, saponin, dan tanin berdasar Chairul (2003).

2. Komponen Pengomposan limbah sayur Variabel diamati saat pengomposan, dimulai dari awal pengomposan hingga akhir pengomposan, meliputi suhu, $\mathrm{pH}$ akhir kompos, $\mathrm{C} / \mathrm{N}$ ratio kompos, kepadatan konidium dalam kompos, dan kegigasan konidium T. harzianum. Suhu diukur pada saat pengomposan limbah setiap 3 hari sekali dimulai dari hari ke-0 pengomposan. Suhu diukur menggunakan thermometer. $\mathrm{pH}$ akhir kompos diukur dengan mengunakan $\mathrm{pH}$ meter. Rasio $\mathrm{C} / \mathrm{N}$ dihitung dengan cara membagi nilai $\mathrm{C}$-organik dengan $\mathrm{N}$ total. C-organik dicari dengan metode Walkey dan black Kolorimetri, dan Ntotal dicari dengan metode Kjeldah (Balai Penelitian Tanah, 2005). Pengukuran N-total dan C-organik dilakukan sebelum dan sesudah pengkomposan.

3. Komponen pertumbuhan

Variabel pertumbuhan yang diamati dalam penelitian ini antara lain panjang tanaman, jumlah daun, panjang akar, bobot tanaman segar, dan bobot tanaman kering yang dilakukan di akhir penelitian (40 hari setelah tanam).

Data yang diperoleh ditabelkan, kemudian dianalisis dengan uji F. Apabila terdapat perbedaan nyata dilanjutkan dengan Duncan's Multiple Range Test (DMRT) pada taraf 5\%.

\section{HASIL DAN PEMBAHASAN}

\section{Analisis kandungan fenol}

Berdasarkan hasil pengujian secara kualitatif kandungan glikosida, kandungan gikosida tertinggi yaitu pada $T$. harzianum T10 kompos kubis dan T. harzianum T14 kompos kubis (Tabel 1). Hal tersebut ditunjukkan dengan adanya warna lembayung. Perubahan warna menjadi lembayung tersebut menunjukkan reaksi positif pada 2-deoksida-gula. Menurut 
Chairul (2003), tanaman yang memiliki

intensitas penyakit menjadi tinggi. kandungan fenol rendah, sehingga

Demikian jika kandungan fenol tinggi, maka intensitas penyakitnya rendah.

Tabel 1. Analisis kandungan fenol secara kualitatif

\begin{tabular}{lccc}
\hline \multicolumn{1}{c}{ Perlakuan } & \multicolumn{3}{c}{ Kandungan fenol (kualitatif) } \\
\cline { 2 - 4 } & Saponin & Tanin & Glikosida \\
\hline Kompos tomat & ++ & + & +++ \\
T. harzianum T10, kompos tomat & ++ & ++ & ++ \\
T. harzianum T14, kompos tomat & ++ & + & ++ \\
T. harzianum T16, kompos tomat & ++ & ++ & + \\
T. harzianum T213, kompos tomat & +++ & + & + \\
Kompos kubis & ++ & + & + \\
T. harzianum T10, kompos kubis & +++ & ++ & ++ \\
T. harzianum T14, kompos kubis & ++ & + & +++ \\
T. harzianum T16, kompos kubis & ++ & + & + \\
T. harzianum T213, kompos kubis & +++ & + & +++ \\
\hline Ketrangan: (-) tidak mandung
\end{tabular}

Keterangan: (-) tidak mengandung fenol, (+) sedikit mengandung fenol, (++) cukup mengandung fenol, $(+++)$ banyak mengadung fenol.

Tanin yang relatif lebih tinggi terdapat pada tanaman yang diperlakukan dengan $T$. harzianum T10 kompos tomat. Hal ini menunjukkan bahwa pada perlakuan T. harzianum $\mathrm{T} 10$ kompos tomat, $T$. harzianum T16 kompos tomat, dan $T$. harzianum T10 kompos kubis mengandung senyawa tanin yang lebih banyak dibandingkan perlakuan yang lain. Menurut Salminen and Karonen (2011), tanin merupakan kelompok metabolit sekunder tanaman yang berperan dalam pengaktifan sistem pertahanan tanaman terhadap patogen, seperti halnya dengan kandungan glikosida dan saponin.

\section{Komponen Pengomposan Limbah Sayur}

Suhu pada perlakuan T. harzianum T16 kompos kubis lebih rendah dibandingkan dengan suhu perlakuan lain, sedangkan perlakuan kompos tomat lebih konstan. Suhu tertinggi pada perlakuan $T$. harzianum T10 dan kompos kubis yang mencapai $31,1^{\circ} \mathrm{C}$ (Tabel 2). Keadaan ini menunjukkan bahwa pada kompos telah terjadi pengomposan atau penguraian bahan organik oleh isolat $T$. harzianum. Semakin tinggi suhu akan meningkatkan aktivitas mikroba dan, karena itu, meningkatkan konsumsi oksigen dalam air, akibatnya memengaruhi $\mathrm{pH}$ dan laju ion dan pembebasan nutrisi (Lin et al., 2016). Lebih lanjut Sobari et al. (2018) menjelaskan mikroba dalam proses pembuatan kompos akan melepaskan energi panas dalam proses karbonasi. Pada saat penguraian bahan organik yang sangat aktif, mikroba yang ada di dalam kompos mulai melakukan metabolisme dengan cara menguraikan dan merubah bahan organik menjadi $\mathrm{NH}^{+}, \mathrm{CO} 2$, uap air dan panas 
dengan bantuan oksigen. Hal ini yang menyebabkan stuktur tanah yang padat menjadi gembur.

Perlakuan kompos kubis $T$. harzianum T10 memiliki suhu yang tertinggi dibandingkan dengan perlakuan lainnya yaitu $31,1^{\circ} \mathrm{C}$, sementara yang terendah adalah perlakuan kompos kubis $T$. harzianum T16 yaitu $29,6^{\circ} \mathrm{C}$. Perbedaan suhu ini dikarenakan kemampuan $T$. harzianum T10 dan T. harzianum T16 dalam mengomposkan limbah kubis berbeda.

Hal ini menunjukkan bahwa mikroba

Tabel 2. Suhu dan $\mathrm{pH}$ pada proses pembuatan kompos bahan limbah tomat dan kubis

\begin{tabular}{lcc}
\hline \multicolumn{1}{c}{ Perlakuan } & suhu $\left({ }^{\circ} \mathrm{C}\right)$ & $\mathrm{pH}$ \\
\hline Kompos tomat & 30,5 & - \\
T. harzianum T10, kompos tomat & 30,5 & 7,88 \\
T. harzianum T14, kompos tomat & 30,9 & 8,31 \\
T. harzianum T16, kompos tomat & 30,9 & 8,18 \\
T. harzianum T213, kompos tomat & 30,3 & 7,42 \\
Kompos kubis & 30,5 & - \\
T. harzianum T10, kompos kubis & 31,1 & 8,01 \\
T. harzianum T14, kompos kubis & 30,2 & 7,73 \\
T. harzianum T16, kompos kubis & 29,6 & 8,24 \\
T. harzianum T213, kompos kubis & 30,4 & 7,72 \\
\hline
\end{tabular}

Semua isolat $T$. harzianum mampu meningkatkan $\mathrm{pH}$ kompos (Tabel 2). $\mathrm{pH}$ adalah salah satu parameter terpenting pengomposan, karena kepekaan mikroba terhadap variasi $\mathrm{pH} . \mathrm{pH}$ antara 7,0 dan 8,0 sesuai untuk degradasi protein dan antara 6,0 dan 9,0 untuk degradasi karbohidrat. Pada bakteri fermentasi, kisaran $\mathrm{pH}$ komprehensif dari 4,0 hingga 8,5 adalah sesuai (Fisgativa et al., 2016). Bahan organik dengan nilai $\mathrm{pH}$ 3-11 dapat pengompos yang berbeda akan berpengaruh kepada perbedaan peningkatan suhu kompos. Sesuai dengan pernyataan Palaniveloo et al. (2020), yang mengatakan bahwa perubahan komposisi spesies makrofungi saprotrofi dan fauna tanah mikofagus dapat mengubah siklus nutrisi dan pernapasan $\mathrm{CO}_{2}$, yang akan berdampak pada peningkatan suhu. Proses menghasilkan panas, $\mathrm{CO}_{2}$, uap $\mathrm{H}_{2} \mathrm{O}$, dan humus sebagai hasil dari pertumbuhan dan aktivitas mikroba (Ayilara et al., 2020). 
mendorong pertumbuhan jamur dan akan mengompos lignin dan selulosa pada bahan kompos. Selama pembuatan kompos berlangsung, asam-asam organik tersebut akan menjadi netral dan kompos menjadi matang biasanya mencapai $\mathrm{pH}$ antara 6-8. Hal ini sesuai dengan hasil penelitian Fersi et al. (2019), yang mengatakan bahwa dalam tumpukan limbah, ada dua fase berturut-turut yang terjadi, yaitu alkalisasi dan stabilisasi. Selama fase pertama, $\mathrm{pH}$ meningkat. Alkalisasi medium pada dasarnya disebabkan oleh hilangnya asam organik termasuk senyawa lemak dan fenol yang terurai. Peningkatan $\mathrm{pH}$ adalah hasil dari penguapan dan penguraian mikroba asam organik, dan pelepasan amonia oleh pemineralan mikroba dari sumber nitrogen organik (Lori et al., 2017).

Kompos limbah tomat mempunyai $\mathrm{C} / \mathrm{N}$ ratio 4,24 dan pada perlakuan kompos limbah kubis, C/N rationya 7,00. Kandungan $\mathrm{C}$ organik tertinggi adalah kompos limbah tomat sebesar 1,276\% dan terendah adalah kompos limbah kubis sebesar 0,812\% (Tabel 3). Hal ini terjadi karena jumlah komposisi memiliki pengaruh yang berarti terhadap tumbuh kembangnya mikroba, mikroba tumbuh baik dengan banyaknya unsur $\mathrm{C}$ dan unsur lainnya.

Kandungan N total (Tabel 3) kompos limbah limbah tomat sebesar 0,301\%, sedangkan pada kompos limbah kubis sebesar $0,116 \%$. Rasio $\mathrm{C} / \mathrm{N}$ masing-masing kompos mengalami penurunan. Hal ini disebabkan bahan mengalami pengomposan. $\mathrm{C}$ organik dalam bahan sebagai sumber makanan bagi mikroba, sehingga jumlahnya berkurang. Selain itu, $\mathrm{C}$ organik juga terurai menjadi $\mathrm{CO}_{2}$ ke udara. $\mathrm{N}$ total dalam bahan mengalami peningkatan karena pengomposan bahan kompos oleh mikroba yang menghasilkan ammonia dan nitrogen, sehingga kadar $\mathrm{N}$ total kompos meningkat (Pan et al., 2012).

Menurunnya kandungan $\mathrm{C}$ organik dan meningkatnya kandungan $\mathrm{N}$ total, menyebabkan rasio $\mathrm{C} / \mathrm{N}$ mengalami penurunan. Penurunan rasio $\mathrm{C} / \mathrm{N}$ dapat dijelaskan dengan transformasi karbon organik menjadi karbon dioksida, diikuti dengan pengurangan kadar asam organik (Sanmanee et al., 2011).

Jamur memerlukan hara untuk mendukung pertumbuhannya dan unsur karbon adalah salah satu senyawa pembangun sel, sehingga semakin banyak sel yang hidup semakin banyak karbon yang digunakan untuk pertumbuhannya (Itoo and Resh, 2014). Pada saat karbon digunakan untuk perkembangan $T$. harzianum, nisbah $\mathrm{C} / \mathrm{N}$ ratio akan menurun, sehingga tercapai keadaan kompos dikatakan matang. Kompos matang memiliki bau seperti tanah dan warna kehitaman yang terbentuk akibat pengaruh bahan organik yang sudah stabil (Suwatanti 
dan Widiyaningrum, 2017). Perbedaan antar-isolat $T$. harzianum di dalam mengomposkan limbah sayur disebabkan perbedaan di dalam menghasilkan senyawa bioaktif berupa enzim selulose. Hal ini Tabel 3. $\mathrm{C} / \mathrm{N}$ ratio akhir kompos

\begin{tabular}{cccc}
\hline Perlakuan & C organik (\%) & N total (\%) & C/N ratio akhir \\
\hline Kompos limbah tomat & 1,276 & 0,301 & 4,224 \\
Kompos limbah kubis & 0,812 & 0,116 & 7,000 \\
\hline
\end{tabular}

Tabel 4. Kepadatan konidium kompos bulan ke-0 sampai bulan ke-3

\begin{tabular}{|c|c|c|c|c|c|}
\hline \multirow{2}{*}{ Perlakuan } & \multicolumn{4}{|c|}{$\begin{array}{l}\text { Kepadatan konidium kompos } \\
\left(\times 10^{8} \mathrm{upk} / \mathrm{g}\right) \text { bulan ke- }\end{array}$} & \multirow{2}{*}{$\begin{array}{c}\text { Perubahan } \\
\text { kepadatan } \\
\text { Konidium } \\
(\%)\end{array}$} \\
\hline & 0 & 1 & 2 & 3 & \\
\hline T. harzianum $\mathrm{T} 10$, kompos tomat & 3,85 & 3,72 & 3,00 & 29,20 & $(+) 86,81$ \\
\hline T. harzianum $\mathrm{T} 14$, kompos tomat & 3,98 & 3,98 & 29,90 & 2,79 & $(-) 29,89$ \\
\hline T. harzianum T16, kompos tomat & 4,78 & 4,33 & 2,86 & 3,01 & $(-) 37,02$ \\
\hline T. harzianum $\mathrm{T} 213$, kompos tomat & 49,00 & 4,74 & 2,85 & 2,79 & $(-) 43,06$ \\
\hline T. harzianum T10, kompos kubis & 4,80 & 4,74 & 3,40 & 2,66 & $(-) 44,58$ \\
\hline T. harzianum $\mathrm{T} 14$, kompos kubis & 4,90 & 4,03 & 3,19 & 25,50 & $(+) 80,78$ \\
\hline T. harzianum T16, kompos kubis & 4,65 & 4,53 & 3,22 & 2,66 & $(-) 42,79$ \\
\hline T. harzianum $\mathrm{T} 213$, kompos kubis & 4,68 & 4,62 & 3,15 & 2,56 & $(-) 45,29$ \\
\hline
\end{tabular}

Keterangan: $(+)=$ meningkat; $(-)=$ menurun.

Hasil pengamatan empat isolat $T$. harzianum pada pengamatan awal, bulan ke-0 sampai dengan bulan ke-3 terjadi fluktuasi jumlah konidium (Tabel 4). Hasil pengamatan jumlah konidium $T$. harzianum pada limbah tomat dengan jumlah konidium tertinggi adalah $T$. harzianum $\mathrm{T} 10$ sebesar $2,92 \times 10^{9}$ upk/g dengan persentase peningkatannya sebesar $86,81 \%$, sedangkan pada limbah kubis, jumlah konidium tertinggi adalah T. harzianum T14 sebesar $2,55 \times 10^{9}$ upk/g dengan persentase peningkatan sebesar $80,78 \%$. Pemberian $T$. harzianum T14 pada limbah tomat mampu sesuai pernyataan Błaszczyk et al. (2016), bahwa terdapat keragaman antar-isolat Trichoderma sp. di dalam kompetisi pengomposan bahan organik. 
harzianum bahkan jumlah konidium yang dihasilkan menurun.

Pada perlakuan T. harzianum T10 dan T. harzianum $\mathrm{T} 14$, yang mengalami peningkatan jumlah konidium, diduga karena kandungan nutrisi mencukupi dan lingkungan sesuai untuk perkembangan jumlah konidium. T. harzianum menunjukkan diameter zona bening yang lebih tinggi daripada Trichoderma spp. pada media yang mengandung kitin dan selulosa (Zehra et al., 2017). Peningkatan populasi antagonis $T$. harzianum juga dipengaruhi oleh lingkungan hidupnya. Beberapa faktor abiotik seperti suhu, logam berat, hubungan air, garam, $\mathrm{pH}$, dan bahkan pestisida telah dilaporkan merusak sifat antagonis spesies Trichoderma terhadap jamur patogen tanaman (Petrisor et al., 2016; Zehra et al., 2017). Selama interaksi miselium, suhu yang meningkat hanya meningkatkan pertumbuhan pesaing yang dominan; peningkatan pertumbuhan oleh pesaing yang lebih rendah dicegah dengan antagonisme oleh adanya $T$. harzianum (A'Bear et al., 2013).

Hasil pengamatan kegigasan konidium kompos $T$. harzianum dapat dilihat pada (Tabel 5). Hasil kegigasan semua isolat $T$. harzianum pada bulan ke-0 sampai bulan ke-3 mengalami penurunan. Penurunan tertinggi pada kompos tomat yang diberi perlakuan $T$. harzianum isolat jahe sebesar 33,35\%, sedangkan penurunan terendah pada kompos kubis yang diberi perlakuan T. harzianum T213 sebesar Tabel 5. Kegigasan konidium kompos T. harzianum bulan ke-0 sampai ke-3

\begin{tabular}{|c|c|c|c|c|c|}
\hline \multirow{2}{*}{ Perlakuan } & \multicolumn{4}{|c|}{ Kegigasan konidium(\%) bulan $\mathrm{Ke}-$} & \multirow{2}{*}{$\begin{array}{l}\text { Perubahan } \\
\text { kegigasan }\end{array}$} \\
\hline & 0 & 1 & 2 & 3 & \\
\hline T. harzianum $\mathrm{T} 10$, kompos tomat & 95,31 & 81,23 & 74,75 & 61,96 & $(-) 33,35$ \\
\hline T. harzianum $\mathrm{T} 14$, kompos tomat & 86,63 & 84,55 & 71,39 & 62,67 & $(-) 23,96$ \\
\hline T. harzianum $\mathrm{T} 16$, kompos tomat & 88,14 & 77,59 & 74,00 & 55,72 & $(-) 32.42$ \\
\hline T. harzianum $\mathrm{T} 213$, kompos tomat & 96,25 & 82,30 & 71,19 & 61,17 & $(-) 34,54$ \\
\hline T. harzianum $\mathrm{T} 10$, kompos kubis & 85,03 & 77,57 & 74,75 & 60,91 & $(-) 24,12$ \\
\hline T. harzianum $\mathrm{T} 14$, kompos kubis & 89,12 & 78,33 & 76,56 & 61,75 & $(-) 27,37$ \\
\hline T. harzianum $\mathrm{T} 16$, kompos kubis & 84,75 & 75,85 & 75,56 & 61,08 & $(-) 23,67$ \\
\hline T. harzianum $\mathrm{T} 213$, kompos kubis & 89,23 & 85,32 & 74,15 & 67,60 & $(-) 21,63$ \\
\hline
\end{tabular}

Keterangan: $(+)=$ meningkat; $(-)=$ menurun.

21,63\%. Fluktuasi kegigasan konidium dapat disebabkan waktu penyimpanan yang semakin lama, menyebabkan kegigasan T. harzianum akan menurun. Penurunan kegigasan konidium dapat disebabkan oleh faktor nutrisi dari medium, suhu dan kelembapan sama seperti jumlah konidium (Piegza et al., 2017). Sumber karbon dan nitrogen berpengaruh terhadap pensporaan dan pertumbuhan T. harzianum (Rajput et al., 2014; Rai and Tewari, 2016). 


\section{Komponen Pertumbuhan}

Hasil analisis statistika pada semua variabel menunjukkan adanya perbedaan yang nyata antar-perlakuan (Tabel 6). Semua perlakuan dapat meningkatkan pertumbuhan tanaman mentimun.Pada variabel pengamatan jumlah daun menunjukkan perbedaan yang tidak nyata.

Hasil penelitian menunjukkan (Tabel 6), panjang tanaman mentimun tertinggi pada akhir pengamatan terlihat pada pemberian kompos tomat dengan perlakuan T. harzianum $\mathrm{T} 16$ adalah $51,71 \mathrm{~cm}$ atau meningkat $61,61 \%$ dibandingkan isolat T213 dan terendah pada perlakuan kompos tomat dengan perlakuan T. harzianum T213 adalah 19,85 cm. Hal ini menunjukkan bahwa kompos tomat dengan T. harzianum T16 menyediakan unsur hara bagi tanaman. Rerata panjang tanaman mentimun tertinggi dihasilkan oleh pemberian kompos kubis dengan perlakuan T. harzianum $\mathrm{T} 10$ adalah $61,22 \mathrm{~cm}$ atau meningkat 52,17\% disbanding isolat T14 dan tidak berbeda nyata dengan isolat T16 dibandingkan pemberian kompos kubis dengan perlakuan T. harzianum $\mathrm{T} 14$ adalah $29,28 \mathrm{~cm}$, dan tidak berbeda nyata dengan isolat T16 dan T213. Hal ini disebabkan oleh sedikitnya jumlah dan jenis unsur hara yang terkandung pada kompos kubis (Tabel 6), sehingga tidak dapat memenuhi kebutuhan tanaman secara keseluruhan. Di dalam pemupupukan tanaman, kompos kubis dengan perlakuan T. harzianum $\mathrm{T} 14$ masih memerlukan tambahan unsur hara lain, sehingga dapat mencukupi kandungan unsur hara yang diperlukan tanaman dan menghasilkan pertumbuhan yang lebih baik.

Pengukuran terhadap panjang akar tanaman mentimun (Tabel 6) menunjukkan, bahwa panjang akar terendah pada kompos tomat T. harzianum T16 dan kompos kubis T. harzianum T213. Panjang akar tanaman mentimun pada kompos tomat $T$. harzianum $\mathrm{T} 10$ sangat berbeda nyata dengan kompos tomat T. harzianum T14. Pada tanaman yang yang diberi kompos kubis T. harzianum T10, juga memberikan hasil yang sangat berbeda nyata dengan kompos kubis $T$. harzianum $\mathrm{T} 14$ dan kompos kubis T. harzianum T16. Panjang akar tanaman mentimun dipengaruhi oleh pemberian kompos yang berbeda. Panjang akar terpanjang dihasilkan oleh tanaman mentimun yang diberi kompos tomat $T$. harzianum T10 dan T16 masing-masing adalah 14,83 dan 14,57 $\mathrm{cm}$ atau masingmasing meningkat 61,01 dan $60,4 \%$ dan kompos kubis $T$. harzianum $\mathrm{T} 10$ adalah $16,82 \mathrm{~cm}$ atau meningkat 46,55\% disbanding isolat T14 (terendah).

Berdasarkan hasil penelitian menunjukkan bahwa panjang akar yang panjang belum tentu memiliki pertumbuhan yang lebih baik. Sistem root merupakan arsitektur kompleks dan memiliki fungsi 
multi-fungsi (Comas et al., 2010). Lebih lanjut dikatakan, akar berfungsi dalam penyerapan nutrisi dalam tanah, sehingga panjang akar akan dipengaruhi oleh keberadaan unsur yang terkandung di dalam tanah, selain dipengaruhi oleh lingkungan dan pengelolaan kanopi.

Hasil analisis statistika retata jumlah daun (Tabel 6) menunjukkan nilai tidak berbeda nyata. Diduga bahwa T. harzianum belum mampu memacu pertumbuhan daun tanaman mentimun. Jumlah daun dipengaruhi oleh lingkungan tumbuh serta ketersediaan unsur hara.

Rerata jumlah daun daun berpengaruh tidak nyata pada semua perlakuan (Tabel 6), hal ini diduga karena semua perlakuan memiliki peranan yang sama di dalam meningkatkan pertumbuhan dan hasil tanaman mentimun. Menurut Roell et al. (2017), tidak terjadinya pengaruh interaksi dua faktor perlakuan karena kedua faktor tidak mampu bersinergi (bekerjasama), sehingga mekanisme kerjanya berbeda atau salah satu faktor tidak berperan secara optimum atau bahkan bersifat antagonis, yaitu saling menekan pengaruh masingmasing.

Hasil penelitian menunjukkan bahwa bobot tanaman segar pada kompos limbah tomat T. harzianum T16 adalah lebih besar dan berbeda nyata secara statistika pada perlakuan semua kompos tomat T. harzianum (Tabel 6) atau meningkat 76,41\%. T. harzianum selain mengkoloni

Tabel 6. Pengaruh perlakuan terhadap komponen pertumbuhan tanaman mentimun pada perlakuan T. harzianum dan kompos

\begin{tabular}{llcccc}
\hline \multicolumn{1}{c}{ Perlakuan } & $\begin{array}{c}\text { Panjang } \\
\text { Tanaman } \\
(\mathrm{cm})\end{array}$ & $\begin{array}{c}\text { Panjang } \\
\text { Akar }(\mathrm{cm})\end{array}$ & $\begin{array}{c}\text { Rerata } \\
\text { jumlah } \\
\text { Daun } \\
\text { (helai) }\end{array}$ & $\begin{array}{c}\text { Bobot } \\
\text { Tanaman } \\
\text { segar }(\mathrm{g})\end{array}$ & $\begin{array}{c}\text { Bobot } \\
\text { tanaman } \\
\text { kering } \\
(\mathrm{g})\end{array}$ \\
\hline T. harzianum T10, kompos tomat & $40,18 \mathrm{a}-\mathrm{d}$ & $14,83 \mathrm{ab}$ & 12,66 & $15,41 \mathrm{bc}$ & $1,65 \mathrm{~b}$ \\
T. harzianum T14, kompos tomat & $32,72 \mathrm{bcd}$ & $10,24 \mathrm{~b}-\mathrm{e}$ & 13,21 & $15,37 \mathrm{bc}$ & $0,70 \mathrm{bc}$ \\
T. harzianum T16, kompos tomat & $51,71 \mathrm{ab}$ & $14,57 \mathrm{abc}$ & 14,57 & $23,91 \mathrm{a}$ & $2,68 \mathrm{a}$ \\
T. harzianum T213, kompos tomat & $19,85 \mathrm{~d}$ & $5,77 \mathrm{e}$ & 13,35 & $5,64 \mathrm{e}$ & $0,59 \mathrm{c}$ \\
T. harzianum T10, kompos kubis & $61,22 \mathrm{a}$ & $16,82 \mathrm{a}$ & 14,01 & $22,97 \mathrm{a}$ & $2,71 \mathrm{a}$ \\
T. harzianum T14, kompos kubis & $29,28 \mathrm{bcd}$ & $8,99 \mathrm{de}$ & 14,11 & $9,24 \mathrm{de}$ & $1,30 \mathrm{bc}$ \\
T. harzianum T16, kompos kubis & $47,45 \mathrm{abc}$ & $11,88 \mathrm{bcd}$ & 14,28 & $18,13 \mathrm{~b}$ & $2,66 \mathrm{a}$ \\
T. harzianum T213, kompos kubis & $32,23 \mathrm{bcd}$ & $9,94 \mathrm{cde}$ & 12,35 & $11,97 \mathrm{~cd}$ & $1,21 \mathrm{bc}$ \\
\hline Ke
\end{tabular}

Keterangan: angka yang diikuti oleh huruf yang berbeda pada kolom yang sama menunjukan perbedaan yang nyata berdasarkan DMRT taraf $5 \%$.

akar, juga mampu mempercepat pertumbuhan, karena diduga menghasikan senyawa kimia yang memacu pertumbuhan.
Hal ini menunjukkan bahwa pemberian kompos tomat $T$. harzianum T16 mampu meningkatkan pertumbuhan tanaman secara 
maksimum. Bobot tanaman mentimun segar tertinggi pada pemberian kompos limbah kubis $T$. harzianum $\mathrm{T} 10$ dan terendah pada kompos kubis T. harzianum T14, dengan peningkatan sebesar 59,77\%. Kompos tersebut diduga mengandung unsur hara yang lebih tersedia bagi pertumbuhan vegetatif tanaman mentimun dibandingkan dengan kompos kubis $T$. harzianum T14 maupun kompos tomat $T$. harzianum T213, yang tidak memberikan bobot tanaman segar lebih besar. Menurut de Freitas Lima et al. (2017), hasil tanaman sangat ditentukan oleh produksi biomassa pada saat masa pertumbuhan tanaman dan pembagian biomassa pada bagian yang dipanen. Produksi biomassa tersebut mengakibatkan pertambahan berat dapat pula diikuti dengan pertambahan ukuran tanaman.

$$
\text { Hasil penelitian (Tabel 6) }
$$
menunjukkan, bahwa bobot tanaman kering pada kompos limbah tomat $T$. harzianum T16 lebih besar dan berbeda nyata pada semua kompos tomat $T$. harzianum atau sebesar 77,99\% dibandingkan kompos tomat T. harzianum T213. Pada kompos limbah kubis T. harzianum T10 atau meningkat $52,03 \%$ dan tidak berbeda nyata dengan isolat T16 adalah lebih besar dan berbeda nyata secara statistika pada kompos tomat T. harzianum $\mathrm{T} 14$ dan T213. Perbedaan berat kering disebabkan oleh pengaruh gabungan dari peningkatan luas daun dan peningkatan laju fotosintesis per satuan luas daun. Peningkatan laju fotosintesis disertai dengan peningkatan luas daun, keduanya memiliki pengaruh nyata pada produksi biomassa (de Freitas Lima et al., 2017; Ogbaga et al., 2019). Sesuai dengan hasil penelitian Azarmi et al. (2011), Trichoderma sp. meningkatkan tinggi tunas, diameter tunas, berat tunas segar dan kering serta berat akar segar dan kering pada bibit tomat.

Oleh karena itu, dapat disimpulkan bahwa empat isolat T. harzianum yang diuji mampu mengomposkan limbah sayur secara cepat dan efektif selama 30 hari. Peningkatan paling baik pada pengomposan limbah sayur adalah T. harzianum T16 pada limbah tomat dan T. harzianum T10 limbah kubis. Aplikasi penggunaan kompos limbah sayur setelah dikomposkan pada pertumbuhan tanaman mentimun mampu meningkatkan pertumbuhan tananaman, dengan cepat.

\section{KESIMPULAN}

Berdasarkan hasil penelitian dapat disimpulkan bahwa aplikasi keempat isolat T. harzainum efektif dan cepat mengkompos limbah tomat dan kubis. Isolat T. harzianum yang paling baik pada pengomposan adalah T10 dan T16. Aplikasi kompos limbah mampu meningkatkan pertumbuhan tanaman mentimun. Isolat terbaik adalah $T$. 
harzianum T16 pada kompos tomat dan T10 pada kompos kubis dalam meningkatkan pertumbuhan tanaman mentimun pada panjang tanaman, panjang akar, bobot tanaman segar, dan bobot tanaman kering dengan peningkatan masing-masing 66,61 dan 52,17\%, 61,01 dan 46,55\%, 76,41 dan 59,77\%, serta 77,99 dan $52,03 \%$.

\section{DAFTAR PUSTAKA}

A'Bear, A.D., W. Murray, R. Webb, L. Boddy, and T.H. Jones. 2013. Contrasting effects of elevated temperature and invertebrate grazing regulate multispecies interactions between decomposer fungi. PLoS ONE, 8(10): e77610.

Ayilara, M.S., O.S. Olanrewaju, O.O. Babalola, and O. Odeyemi. 2020. Waste management through composting: Challenges and potentials. Sustainability, 12: 44-56.

Azarmi, R., B. Hajieghrari, and A. Giglou. 2011. Effect of Trichoderma isolates on tomato seedling growth response and nutrient uptake. African Journal of Biotechnology, 10(31): 58505855 .

Balai Penelitian Tanah. 2005. Petunjuk teknis analisis kimia tanah, tanaman, air dan tanaman. Departemen Pertanan, Jakarta.

Badan Pusat Statistik. 2017. Tanaman Hortikultura: Tabel hasil produksi tanaman ketimun Indonesia. https://www.bps.go.id/site/resultTab [20 Oktober 2020].

Bhale, U.N. and J.N. Rajkonda. 2012. Enzymatic activity of Trichoderma species. Novus Natural Science Research, 1(4): 1-8.
Błaszczyk, L., J. Strakowska, J. Chełkowski, A. Gąbka-Buszek, and J. Kaczmarek. 2016. Trichoderma species occurring on wood with decay symptoms in mountain forests in Central Europe: genetic and enzymatic characterization. Journal of Applied Genetics, 57: 397-407.

Chairul. 2003. Identifikasi secara cepat bahan bioaktif pada tumbuhan di lapangan. Berita Biologi, 6: 621-628.

Comas, L.H., T.L. Bauerle, and D.M. Eissenstat. 2010. Biological and environmental factors controlling root dynamics and function: effects of root ageing and soil moisture. Australian Journal of Grape and Wine Research, 16(s1): 131-137.

de Freitas Lima, M., N.B. Eloy, J.A.B. deSiqueira, D. Inzé, A.S. Hemerly, and P.C.G. Ferreira. 2017. Molecular mechanisms of biomass increase in plants. Biotechnology Research and Innovation, 1(1): 14-25.

Elpawati, S.D. Dara Y.K.S., dan Dasumiati. 2015. Optimalisasi penggunaan pupuk kompos dengan penambahan Effective Microorganism 10 (EM10) pada produktivitas tanaman jagung (Zea mays L.). Al-Kauniyah Jurnal Biologi, 8(2): 77-87.

Fersi, M., K. Mbarki, K. Gargouri, T. Mechichi, and R. Hachicha. 2019. Assessment of organic matter biodegradation and physico-chemical parameters variation during cocomposting of lignocellulosic wastes with Trametes trogii inoculation. Environmental Engineering Research, 24(4): 670-679.

Fisgativa, H., A. Tremier, and P. Dabert. 2016. Characterizing the variability of food waste quality: A need for efficient valorisation through anaerobic digestion. Waste Manag, 50: 264-274. 
Ghasemzadeh, A. and N. Ghasemzadeh. 2011. Flavonoids and phenolic acids: Role and biochemical activity in plants and human. Journal of Medicinal Plants Research, 5(31): 6697-6703.

Ghazanfar, M.U., M. Raza, W. Raza, and M.I. Qamar. 2018. Trichoderma as potential biocontrol agent, its exploitation in agriculture: A review. Plant Protection, 2(3): 109-135.

Gmach, M.R., M.R. Cherubin, K. Kaiser, and C.E.P. Cerri. 2020. Processes that influence dissolved organic matter in the soil: a review. Scientia Agricola, 77(3): $1-10$.

Hermawan. 2013. Keefektifan empat isolat bakteri antagonis terhadap penyakit hawar daun Phytopthora infestans pada tanaman kentang di lapangan endemis. Skripsi. Fakultas Pertanian Universitas Jenderal Soedirman, Purwokerto 66 hal (Tidak dipublikasikan).

Heydari, A. and M. Pessarakli. 2010. A review on biological control of fungal plant pathogens using microbial antagonists. Journal of Biological Sciences, 10(4): 273-290.

Ishangulyyev, R., S. Kim, and S.H. Lee. 2019. Understanding Food Loss and Waste-Why Are We Losing and Wasting Food? Foods, 8(8): 297.

Islam, M.A., M.G. Mostafa, and M.R. Rahman. 2014. Conversion of solid organic waste into compost using Trichoderma spp. and its application on some selected vegetables. International Journal of Environment and Waste Management, 14(3): 211221.

Itoo, Z.A. and Z.A. Reshi. 2014. Effect of different nitrogen and carbon sources and concentrations on the mycelial growth of ectomycorrhizal fungi under in-vitro conditions.
Scandinavian Journal of Forest Research, 29(7): 619-628.

Latifah, A., Kustantinah, dan L. Soesanto. 2012. Pemanfaatan beberapa isolat Trichoderma harzianum sebagai agensia pengendali hayati penyakit layu fusarium pada bawang merah in planta. Eugenia, 17(2):86-94.

Lin, Q., G. He, J. Rui, X. Fang, Y. Tao, J. $\mathrm{Li}$, and X. Li. 2016. Microorganismregulated mechanisms of temperature effects on the performance of anaerobic digestion. Microb Cell Fact., 15: 96.

Liu, C.-W., Y. Sung, B.-C. Chen, and H.-Y. La. 2014. Effects of nitrogen fertilizers on the growth and nitrate content of lettuce (Lactuca sativa L.). Int. J. Environ. Res. Public Health, 11(4): 4427-4440.

Lori, M., S. Symnaczik, P. Mäder, G. De Deyn, and A. Gattinger. 2017. Organic farming enhances soil microbial abundance and activity-A meta-analysis and meta-regression. PLoS ONE, 12(7): e0180442.

Munir, S., Q. Jamal, K. Bano, S.K. Sherwani, T.Z. Bokhari, T.A. Khan, R.A. Khan, A. Jabbar, and M. Anees. 2013. Biocontrol ability of Trichoderma. International Journal of Agriculture and Crop Sciences, 6(18): 1246-1252.

Ogbaga, C., A.K. Bajhaiya, and S.K. Gupta. 2019. Improvements in biomass production: Learning lessons from the bioenergy plants maize and sorghum. Journal of Environmental Biology, 40(3): 400-406.

Padmi, T., M. Dewiandratika, and E. Damanhuri. 2018. An environmental and economic comparison of fruit and vegetable waste treatment in the traditional markets. International Journal of GEOMATE, 15(49): 9-16.

Palaniveloo, K., M.A. Amran, N.A. Norhashim,.N. Mohamad-Fauzi, F. 
Peng-Hui, L. Hui-Wen, Y. Kai-Lin, L. Jiale, M.G. Chian-Yee, L. Jing-Yi, B. Gunasekaran, and S.A. Razak. 2020. Food waste composting and microbial community structure profiling. Processes, 8(723): $1-30$.

Pan, I., B. Dam, and S.K. Sen. 2012. Composting of common organic wastes using microbial inoculants. Biotech. 2(2): 127-134.

Petrisor, C., A. Paica, and F. Constantinescu. 2016. Influence of abiotic factors on in vitro growth of Trichoderma strains. Proc. Rom. Acad., Series B., 18(1): 11-14.

Piegza, M., A, Kancelista, W. Łaba, and D. Witkowska. 2017. Impact of selected factors on Trichoderma sporulation and biosynthesis of hydrolases in bioreactor. Acta Sci. Pol. Biotechnologia, 16(1): 19-32.

Rai, D. and A.K. Tewari. 2016. Evaluation of different carbon and nitrogen sources for better growth and sporulation of $T$. harzianum (Th14). Journal of Agricultural Biotechnology and Sustainable Development, 8(8): 67-70.

Rajput, A.Q., M.A. Khanzada, and S. Shahzad. 2014. Effect of different organic substrates and carbon and nitrogen sources on growth and shelf life of Trichoderma harzianum. Journal of Agricultural Science and Technology, 16(4): 731-745.

Roell, K.R., D.M. Reif, and A.A. Motsinger-Reif. 2017. An introduction to terminology and methodology of chemical synergyPerspectives from across disciplines. Front Pharmacol., 8: 158.

Salminen, J.-P. and M. Karonen. 2011. Chemical ecology of tannins and other phenolics: we need a change in approach. Functional Ecology, 25(2): 325-338.
Samaniego, L.J.J., P. Murcia, M.A. Bustamante, C. Paredes, A. PerezEspinosa, I. Gavilanes, M. López, F.C.M. Egea, H. Brito, and R. Moral. 2017. Development of organic fertilizers from food market waste and urban gardening by composting in Ecuador. PLoS ONE, 12(7): $\mathrm{e} 0181621$.

Sanmanee, N., K. Panishkan, K. Obsuwan, and S. Dharmvanij. 2011. Study of compost maturity during humification process using UVSpectroscopy. World Academy of Science, Engineering and Technology International Journal of Agricultural and Biosystems Engineering, 5(8): 448-450.

Sobari, E., F. Fathurohman, dan M.A. Hadi. 2018. Karakter pertumbuhan kacang tanah (Arachis hypogaea L.) dengan pemanfaatan kompos limbah baglog jamur dan kotoran domba. Agrin, 22(2): 116-122.

Soesanto, L., E. Mugiastuti, R.F. Rahayuniati, dan R.S. Dewi. 2013. Uji kesesuaian empat isolat Trichoderma spp. dan daya hambat in vitro terhadap beberapa patogen tanaman. Jurnal HPT Tropika, 13(2): 117-123.

Srivastava, N.S.L., S.L. Narnaware, J.P. Makwana, S.N. Singh, and S. Vahora. 2014. nvestigating the energy use of vegetable market waste by briquetting. Renewable Energy, 68: $270 \mathrm{e} 275271$.

Suwatanti, E.P.S. dan P. Widiyaningrum. 2017. Pemanfaatan MOL limbah sayur pada proses pembuatan kompos. Jurnal MIPA, 40(1): 1-6.

Varma, V.S. and A.S. Kalamdhad. 2014. Effects of leachate during vegetable waste composting using rotary drum composter.

Environmental Engineering Research, 19(1): 1 - 7 . 
p-ISSN: 1410-0029; e-ISSN2549-6786

Agrin Vol. 24, No. 2, Oktober 2020

Zehra, A., M.K. Dubey, M. Meena, and R.S. Upadhyay. 2017. Effect of different environmental conditions on

growth and sporulation of some Trichoderma species. Journal of Environmental Biology, 38: 197-203. 